\title{
Closed-loop circuit for reduce oxygen waste on hollow-fiber oxygenators during extracorporeal technologies
}

\author{
Ignazio Condello ${ }^{1 *} \mathbb{C}$, Flavio Rimmaudo ${ }^{2}$ and Giuseppe Speziale
}

Closed-loop systems are designed to dynamically regulate a given variable around a desired set point. Examples thereof surround our everyday lives, from cruise control maintaining the correct speed on the highway, to auto-pilot flying modern airplanes safely [1]. Currently, there are two groups of hollow-fiber membrane oxygenator used in practice. The first types are diffusion, plasma-resistant oxygenators that have been increasingly used for extracorporeal life support or extracorporeal membrane oxygenation for patients who can no longer be supported by mechanical ventilation. The second types are hollow-fiber membranes made of microporous poly-propylene that have been widely used for standard cardiopulmonary bypass (CPB) [2]. Microporous hollow-fiber membranes are primarily used for shortterm cardiopulmonary bypass application, whereas nonmicroporous hollow-fiber membranes are primarily used for extracorporeal membrane oxygenation application (ECMO) [3]. During the use of the oxygenator, the lung membrane uses about $30 \%$ of the medical oxygen delivered by the gas mixer, and the remainder comes out of the gas exhaust and is dispersed into the environment. In this context, we present a closed system aimed at recovering oxygen from the gas outlet of the oxygenator. First, the system recovers through a disposable polymer tube the gas flow from the oxygenator outlet; second, the condensate and water vapor will be removed with a water separator; third, the $\mathrm{CO}_{2}$ will be removed through a soda

*Correspondence: ignicondello@hotmail.it

${ }^{1}$ Department of Cardiac Surgery, Perfusion Service, Anthea Hospital, GVM Care and Research, Via Camillo Rosalba 35/37, 70124 Bari, Italy

Full list of author information is available at the end of the article lime container; fourth, an electric control unit will decide whether to enrich the\% of oxygen recovered through an oxygen source, in relation to the percentage of $\mathrm{FiO}_{2}$ set on the gas mixer (Fig. 1). The closed-loop circuit for oxygenators is a "concept development," and no data are provided on feasibility in this context. The system should be implemented with continuous monitoring to avoid:

- the water separator saturation, through excess water evacuation and appropriate filters

- the risk of increasing pressure in the gas outlet through a safety valve

- the risk for "rebreathing" and hence $\mathrm{CO}_{2}$ accumulation.

Our proposal has the objective of reducing waste and optimizing the use of medical oxygen; at the same time, this closed system is crucial during the transport phases (mostly airplane), in particular for patients on ECMO, to maximize the use of oxygen, guaranteeing greater autonomy.

\section{Acknowledgements \\ Not applicable.}

\section{Authors' contributions}

IC designed the work and the conceptualized the idea. RF gave support for the realization of the manuscript. GS gave support for manuscript language. All authors read and approved the final manuscript.

\section{Funding}

None.

Availability of data and materials Not applicable.

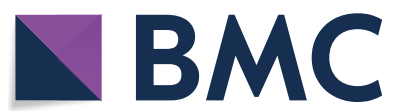

(c) The Author(s) 2021. Open Access This article is licensed under a Creative Commons Attribution 4.0 International License, which permits use, sharing, adaptation, distribution and reproduction in any medium or format, as long as you give appropriate credit to the original author(s) and the source, provide a link to the Creative Commons licence, and indicate if changes were made. The images or other third party material in this article are included in the article's Creative Commons licence, unless indicated otherwise in a credit line to the material. If material is not included in the article's Creative Commons licence and your intended use is not permitted by statutory regulation or exceeds the permitted use, you will need to obtain permission directly from the copyright holder. To view a copy of this licence, visit http://creativecommons.org/licenses/by/4.0/. The Creative Commons Public Domain Dedication waiver (http://creativeco mmons.org/publicdomain/zero/1.0/) applies to the data made available in this article, unless otherwise stated in a credit line to the data. 


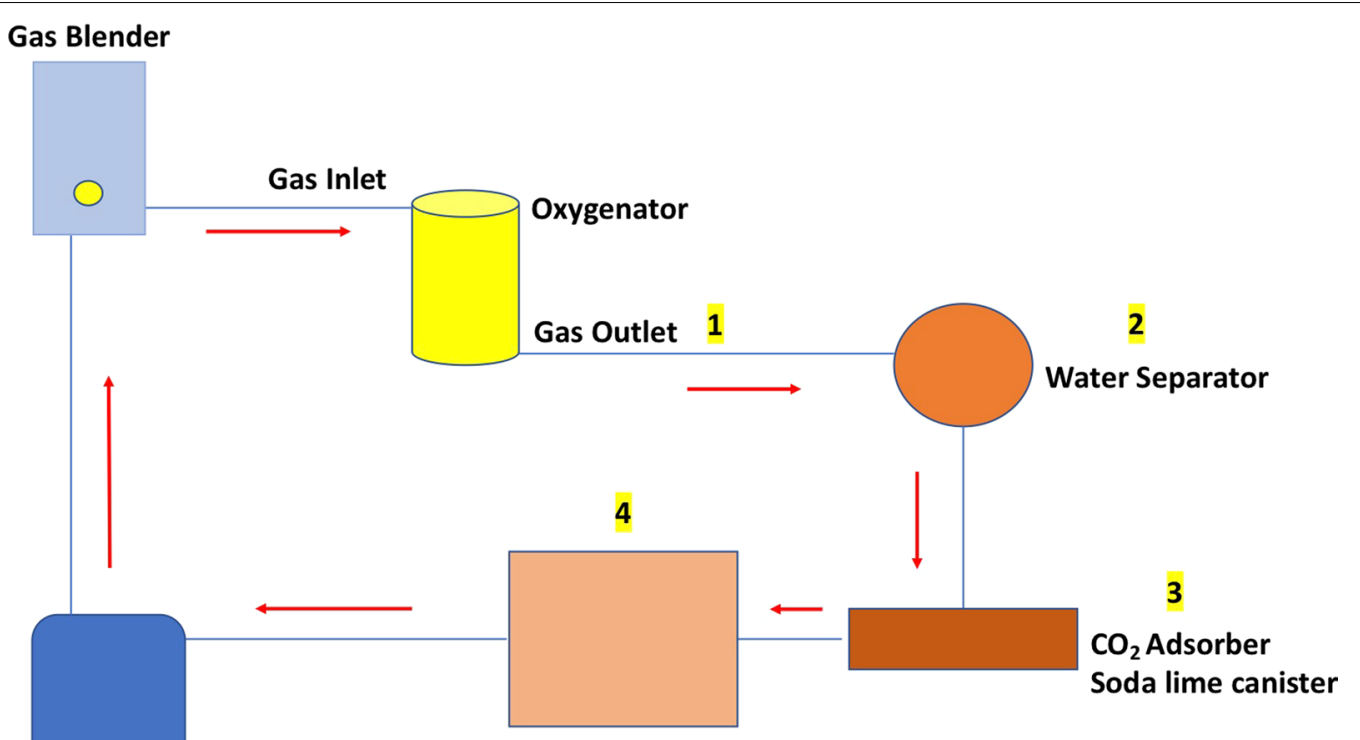

\section{Electric Control Unit}

\section{$\mathrm{O}_{2}$ Supply}

Fig. 1 Closed-loop circuit for reduce oxygen waste on hollow-fiber oxygenators during extracorporeal technologies

Ethical approval and consent to participate

Not applicable.

\section{Consent for publication}

Not applicable.

\section{Competing interests}

None.

\section{Author details}

1 Department of Cardiac Surgery, Perfusion Service, Anthea Hospital, GVM Care and Research, Via Camillo Rosalba 35/37, 70124 Bari, Italy. ${ }^{2}$ Department of Interventional Cardiology, Anthea Hospital, GVM Care and Research, Bari, Italy.

Received: 30 January 2021 Accepted: 18 February 2021

Published online: 25 February 2021

\section{References}

1. Platen, PV, Pomprapa A., Lachmann B, et al. The dawn of physiological closed-loop ventilation-a review. Crit Care 24, 121 (2020). https://doi. org/https://doi.org/10.1186/s13054-020-2810-1

2. Berdajs DA, de Stefano E, Delay D, et al. The new advanced membrane gas exchanger. Interact Cardiovasc Thorac Surg. 2011;13(6):591-6. https:// doi.org/10.1510/icvts.2011.276873.

3. Iwahashi H, Yuri K, Nosé Y. Development of the oxygenator: past, present, and future. J Artif Organs. 2004;7(3):111-20. https://doi.org/10.1007/ s10047-004-0268-6.

\section{Publisher's Note}

Springer Nature remains neutral with regard to jurisdictional claims in published maps and institutional affiliations.

Ready to submit your research? Choose BMC and benefit from:

- fast, convenient online submission

- thorough peer review by experienced researchers in your field

- rapid publication on acceptance

- support for research data, including large and complex data types

- gold Open Access which fosters wider collaboration and increased citations

- maximum visibility for your research: over $100 \mathrm{M}$ website views per year

At BMC, research is always in progress.

Learn more biomedcentral.com/submissions 